\title{
Hyperleptinaemia is associated with impaired gonadotrophin response to GnRH during late puberty in obese girls, not boys
}

\author{
Claire Bouvattier ${ }^{1}$, Najiba Lahlou ${ }^{2}$, Marc Roger ${ }^{2}$ and Pierre Bougnères ${ }^{1,2}$ \\ ${ }^{1}$ Pediatric Endocrinology and ${ }^{2}$ INSERM U342, Saint Vincent de Paul, Paris \\ (Correspondence should be addressed to P F Bougnères, Hôpital Saint Vincent de Paul, Service d'Endocrinologie Pédiatrique, 82 Avenue Denfert \\ Rochereau, 75014 Paris, France)
}

\begin{abstract}
In ob/ob mice, leptin deficiency results in hypogonadotrophic hypogonadism, impaired sexual maturation and infertility, which are all corrected by leptin administration. In humans, pubertal development and menarche are related to the attainment of a critical amount of body fat. To examine whether changes in circulating concentrations of leptin could be a hormonal signal influencing gonadotrophin secretion, we studied 98 adolescents and young adults of both sexes, aged 13-19 years, whose weight varied from normal to massively obese and whose sexual maturation was between Tanner stages 3 and 5. We measured leptin, sex steroids and circulating gonadotrophin concentrations in the basal state and in response to GnRH. In perimenarchial and young adult girls, we found that the LH and FSH responses to GnRH were negatively correlated with body mass index (BMI; $r=-0.45$ and -0.47 respectively, $P<0.0025)$ and circulating leptin $(r=-0.53$ and -0.49 respectively, $P<0.002)$. Decreased LH and FSH responses to GnRH were associated with increased adiposity and hyperleptinaemia. Our data do not establish, but are consistent with a direct neuroendocrine negative effect of excess leptin on the central reproductive system of obese girls. In boys of comparable adiposity, we found no influence of BMI or leptin on gonadotrophin concentrations, which is another aspect of the sexual dimorphism characterizing human leptin physiology.
\end{abstract}

European Journal of Endocrinology 138 653-658

\section{Introduction}

Leptin, a protein coded by the ob gene, is secreted by adipose tissue (1), and possibly brain (2), to serve as a component of a regulatory loop linking body fat mass to food intake and energy expenditure (3). In addition, a role for circulating leptin in the regulation of reproduction is suggested by studies both in animal models and humans. Leptin is necessary for the sexual maturation and reproductive life of rodents. Female ob/ob mice, which have a mutated ob gene and leptin deficiency (1), remain prepubertal indefinitely, with no oestrous cycles. Administration of recombinant leptin not only reverses their obesity, but allows ovulation, pregnancy and parturition (4). Ob receptors are expressed in hypothalamus, pituitary gonadotrophs and ovary, supporting the role of leptin in reproductive physiology $(5,6)$. Leptin accelerates the onset of female puberty in normal mice $(7,8)$, and appears to have a role in the onset of puberty of female rats (9), consistent with previous observations regarding body fat and sexual maturation in both these species $(10,11)$. In humans, the influence of nutrition and body composition on puberty and reproductive physiology has long been recognized (10, 12). Menarche typically occurs at a minimal body weight of $48 \mathrm{~kg}$, independent of the age of sexual maturation (13). Women whose percentage body fat decreases to less than $15 \%$ of the ideal value have disturbed reproductive capacity, whereas obese women have dysfunction of the gonadal hormone system and polycystic ovary syndrome more frequently than lean women (14), and morbidly obese women have an increased rate of infertility $(15,16)$.

Leptin is, at present, the only known marker of adipose tissue the circulating concentration of which increases in linear proportion to the body fat mass (17). A sexual dimorphism of circulating leptin concentrations has been consistently observed in normal and obese adults $(18-20)$ and children $(21,22)$, leptin values being $20-30 \%$ greater in female than in male individuals of comparable body composition. These experimental and clinical observations suggest that serum leptin could serve as a gender-dependent message from the adipose tissue to the reproductive system.

Puberty is characterized by increasing concentrations of gonadal oestradiol in girls and testosterone in boys, driven by increasing concentrations of pituitary gonadotrophins, which are, in turn, regulated by gonadotrophin-releasing hormone $(\mathrm{GnRH})$ released by 
Table 1 Main characteristics of the adolescents studied. Values are means \pm S.D.

\begin{tabular}{lccccc}
\hline & \multicolumn{2}{c}{ Girls $(n=50)$} & & \multicolumn{2}{c}{ Boys $(n=48)$} \\
\cline { 2 - 3 } \cline { 5 - 6 } & $\begin{array}{c}\text { Obese } \\
(n=42)\end{array}$ & $\begin{array}{c}\text { Lean } \\
(n=8)\end{array}$ & & $\begin{array}{c}\text { Obese } \\
(n=35)\end{array}$ & $\begin{array}{c}\text { Lean } \\
(n=13)\end{array}$ \\
\hline Age (years) & $14.7 \pm 0.2$ & $14.1 \pm 0.8$ & & $14 \pm 0.3$ & $14.5 \pm 0.4$ \\
Weight (kg) & $83.6 \pm 2.1$ & $47.3 \pm 3.2$ & & $77.5 \pm 3.2$ & $46.1 \pm 2$ \\
Height (cm) & $160.9 \pm 0.8$ & $156.5 \pm 1.1$ & & $160 \pm 1.8$ & $159.2 \pm 3$ \\
BMl (s.D. & $+6.5 \pm 0.6$ & $0.4 \pm 0.9$ & & $+5.6 \pm 0.7$ & $-1.2 \pm 0.3$ \\
BMl $\left(\mathrm{kg} / \mathrm{m}^{2}\right)$ & $33.4 \pm 0.9$ & $18 \pm 0.8$ & & $31.1 \pm 1$ & $16.8 \pm 0.2$ \\
Leptin $(\mathrm{ng} / \mathrm{ml})$ & $36.4 \pm 1.7$ & $14.3 \pm 2.7$ & & $23 \pm 1.8$ & $5.6 \pm 1.2$ \\
\hline
\end{tabular}

hypothalamic neurones $(23,24)$. In the present study, we attempted to determine the relationship between leptin and gonadotrophin secretion in lean and obese adolescents during the late stages of puberty.

\section{Study participants and methods}

\section{Study participants}

The main characteristics of the study participants are presented in Tables 1 and 2. We recruited 98 pubertal adolescents aged 13-19 years: 50 girls (eight non-obese and 42 obese) and 48 boys (13 non-obese and 35 obese). All of them had completed or were completing their pubertal development. Forty-two of the girls had apparently normal menstrual functioning; eight had not had their first menses. None had hirsutism or hyperandrogenism, or ultrasound or hormonal signs of polycystic ovary syndrome (PCOS). Body mass index (BMI) was defined as the weight in kilograms divided by the square of the height in metres. BMI is considered to be a reliable index of adiposity in pubertal adolescents $(22,25)$. Obesity was defined as a BMI or body weight greater than $120 \%$ of the ideal value for age and height (26). Pubertal staging was performed according to Tanner.

None of the participants was taking any medication or had evidence of metabolic or endocrine disease other than obesity.
Protocols were approved by the institutional review board of University René Descartes-Faculté Cochin Saint Vincent de Paul. All the study participants and their families gave their informed consent to their inclusion in this clinical research study.

\section{Hormone assays}

Gonadal function was assessed by measurement of serum concentrations of oestradiol, luteinizing hormone (LH) and follicle-stimulating hormone (FSH) in basal conditions and in response to GnRH stimulation, during the follicular phase. LH and FSH were measured $15,30,45,60,90$ and $120 \mathrm{~min}$ after i.v. injection of $\mathrm{GnRH} 100 \mu \mathrm{g} / \mathrm{m}^{2}$ (27). Testosterone was measured by a direct radioimmunoassay (Orion, Turku, Finland). The intra- and interassay coefficients of variation were $8 \%$ and $8.5 \%$ respectively for a concentration of $0.6 \mathrm{ng} / \mathrm{ml}$ and $<8 \%$ at greater concentrations, and the limit of detection was $0.05 \mathrm{ng} / \mathrm{ml}$. Oestradiol was measured by a double-antibody radioimmunoassay (Clinical Assays, Stillwater, Minnesota, USA). The intra-assay coefficient of variation was $5.8 \%$ at $25 \mathrm{pg} / \mathrm{ml}$ and $3.2 \%$ at $90 \mathrm{pg} / \mathrm{ml}$, the interassay coefficient of variation was $2.4 \%$ at $26 \mathrm{pg} / \mathrm{ml}$ and $3.8 \%$ at $83 \mathrm{pg} / \mathrm{ml}$, and the limit of detection was $2.5 \mathrm{pg} / \mathrm{ml}$. Leptin was measured in plasma or serum samples by radioimmunoassay by means of reagents supplied by Linco Research Inc. (Saint Louis, Missouri, USA), as reported elsewhere (22).

Table 2 Sexual development and hormones in the adolescents studied. Values are means \pm S.D.

\begin{tabular}{|c|c|c|c|c|}
\hline & \multicolumn{2}{|c|}{ Girls $(n=50)$} & \multicolumn{2}{|c|}{ Boys $(n=48)$} \\
\hline & $\begin{array}{c}\text { Obese } \\
(n=42)\end{array}$ & $\begin{array}{l}\text { Lean } \\
(n=8)\end{array}$ & $\begin{array}{l}\text { Obese } \\
(n=35)\end{array}$ & $\begin{array}{c}\text { Lean } \\
(n=13)\end{array}$ \\
\hline Uterine length (cm) & $62.8 \pm 1.4$ & $62 \pm 1.6$ & - & - \\
\hline Testes volume (ml) & - & - & $10.1 \pm 1.5$ & $10.7 \pm 2.4$ \\
\hline Basal LH (IU/ml) & $3 \pm 0.2$ & $3.4 \pm 0.7$ & $1.4 \pm 0.2$ & $1.8 \pm 0.2$ \\
\hline LH peak* (IU/ml) & $13.4 \pm 0.9$ & $18.6 \pm 1.2$ & $10.4 \pm 1$ & $13.1 \pm 1.7$ \\
\hline Basal FSH (IU/ml) & $3.1 \pm 0.2$ & $3.9 \pm 0.1$ & $1.9 \pm 0.2$ & $2 \pm 0.3$ \\
\hline FSH peak* (IU/ml) & $6.8 \pm 2.4$ & $9.5 \pm 2.8$ & $3.9 \pm 0.4$ & $3.9 \pm 0.8$ \\
\hline Oestradiol (pg/ml) & $46.3 \pm 4.1$ & $45.2 \pm 2.4$ & - & - \\
\hline Testosterone (ng/ml) & - & - & $4.3 \pm 0.5$ & $4.6 \pm 1.1$ \\
\hline
\end{tabular}

*After GnRH. 
The intra-assay coefficient of variation was $3.6 \%$ at $1.4 \mathrm{ng} / \mathrm{ml}$ and $3.3 \%$ at $14.2 \mathrm{ng} / \mathrm{ml}$, the interassay coefficient of variation was $4.6 \%$ at $1.4 \mathrm{ng} / \mathrm{ml}$ and $3.7 \%$ at $14.2 \mathrm{ng} / \mathrm{ml}$. Recovery of human leptin added to a plasma pool was $105 \pm 4 \%$ (mean \pm s.D.). Serial dilutions of high-concentration samples strictly paralleled the standard curve. The mean fasting concentration ( \pm s.D.) was $3.6 \pm 0.7 \mathrm{ng} / \mathrm{ml}$ in non-obese men and $8.8 \pm 3.9 \mathrm{ng} / \mathrm{ml}$ in non-obese menstruating women.

\section{Statistical analysis}

Linear regression analyses were performed relating indices of adiposity and serum leptin concentration. Correlations between gonadotrophin concentrations (basal and peak) and leptin, BMI and age, were calculated. For all statistical tests, significance was defined as $P<0.05$. Computations were made with BMDP statistical software.

\section{Results}

Clinical and biological characteristics of the children studied are presented according to sex in Tables 1 and 2. BMI correlated positively with age $(r=0.81$, $P<0.0001)$. The mean serum leptin concentration was $26.9 \pm 1.8 \mathrm{ng} / \mathrm{ml}$ in the 98 adolescents and $5.5 \pm 1.0 \mathrm{ng} / \mathrm{ml}$ in the lean subgroup (21/98) $(P<0.001)$. Univariate analysis showed that serum leptin correlated strongly with BMI both in girls $(r=0.85, \quad P<0.0001)$ and in boys $(r=0.72$, $P<0.0001)$, but did not correlate with age. In both sexes, in agreement with the findings of others (28), mean basal LH and FSH concentrations showed no correlation with age within our narrow range of pubertal stages.

In girls, basal FSH, but not LH, correlated with BMI $(r=0.45, P<0.005)$. The peak LH response in girls correlated with the basal LH value $(r=0.61$, $P<0.0001)$, and peak FSH correlated with basal FSH $(r=0.84, P<0.0001)$. Peak LH and FSH responses of girls to GnRH test were interrelated $(r=0.35, P<0.04)$, and both correlated negatively with BMI $(r=-0.45$, $P<0.005$ and $-0.47, P<0.0025)$, but not with age. Serum leptin in girls correlated negatively with peak LH $(r=-0.53, P<0.0001$; Fig. 1), basal FSH and peak FSH $(r=-0.49, P<0.002$; Fig. 2). Basal and peak LH/FSH ratios were closely correlated $(r=0.79$, $P<0.0001$ ), but were not influenced by leptin concentrations. Oestradiol concentration did not correlate with basal or peak LH, age, BMI or leptin.

In boys, basal LH and post-GnRH peak were correlated $(r=0.58, P<0.0001)$, in addition to basal and peak FSH concentrations $(r=0.91, P<0.0001)$. Basal and post-GnRH LH and FSH values were interrelated $(r=0.59, P<0.0001$ for each). Correlations of gonadotrophin concentrations with BMI or serum leptin were not found in boys (Figs 1, 2). Testosterone correlated with both basal $(r=0.46, P<0.002)$ and peak LH $(r=0.44, P<0.01)$, and to a lesser degree with leptin $(r=0 \cdot 37, P<0.05)$, but not with age and BMI.
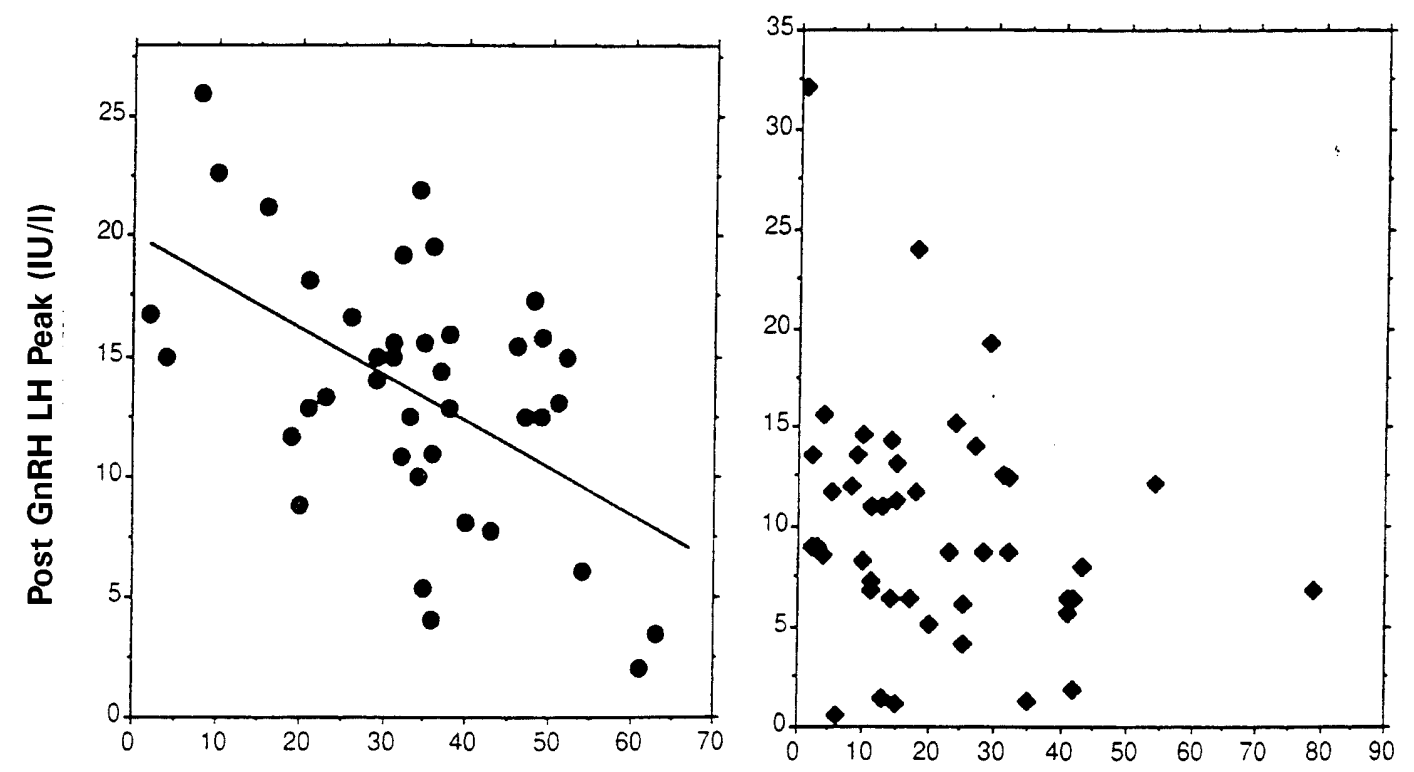

Serum Leptin (ng/ml)

Figure 1 Relationship between serum leptin concentration and maximal LH value after GnRH injection in girls $(\bullet)$ and boys $(\bullet)$. The equation describing the regression of LH peak to leptin in girls is: $y=-0.19 x+20(r=-0.53, \mathrm{P}<0.01)$. There was no significant relationship between these parameters in boys. 

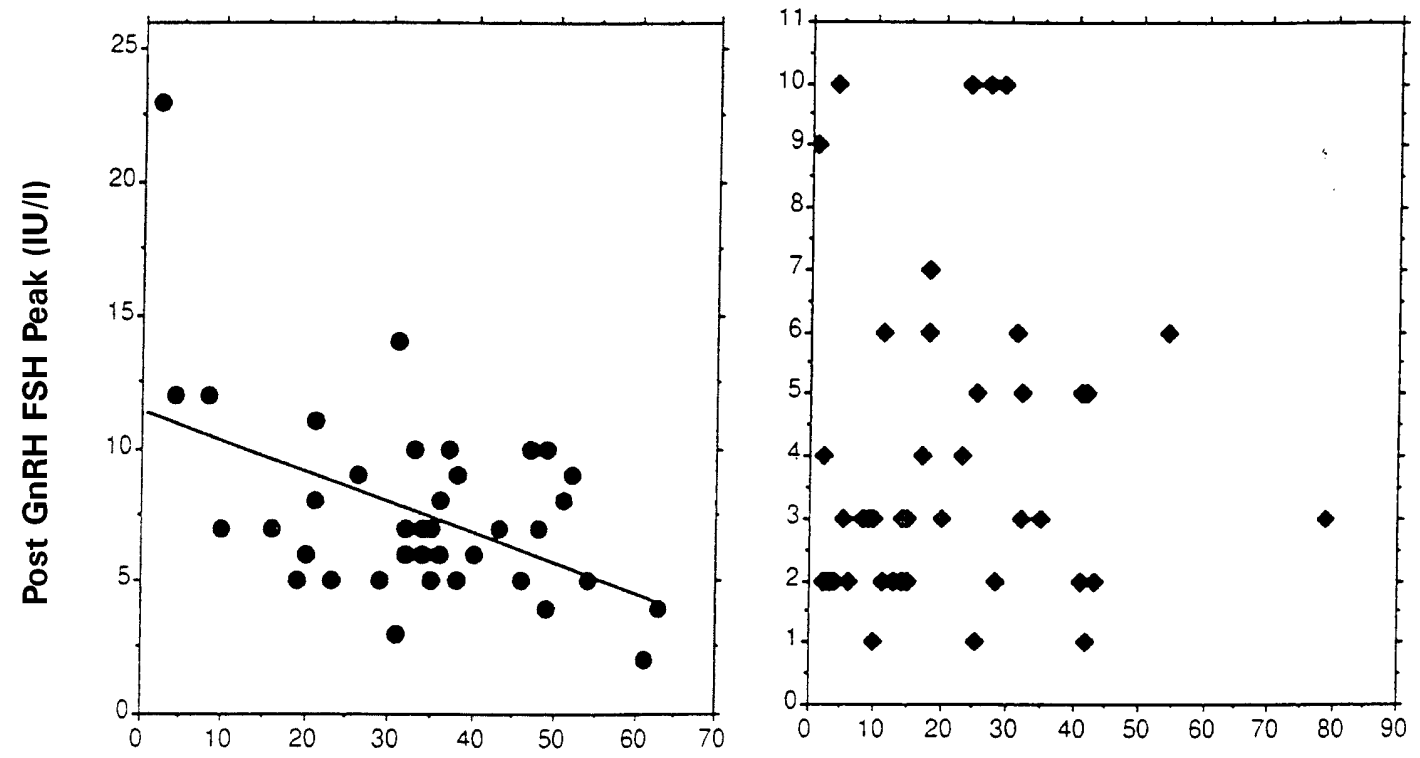

\section{Serum Leptin (ng/ml)}

Figure 2 Relationship between serum leptin concentration and maximal FSH value after GnRH injection in girls $(\bullet)$ and boys $(\bullet)$. The regression equation in girls is: $y=-0.12 x+11.4(r=-0.49, P<0.02)$. There was no significant relationship in boys.

\section{Discussion}

Serum concentrations of leptin in the 98 adolescents (21 lean and 77 obese) were correlated closely with adiposity, as reported previously $(21,22)$. We found that puberty was associated with an increase in leptin values in girls, but that boys retained lower values for leptin than did the girls, and showed no increase after sexual maturation (22); these data confirmed the observations of others (28-30). The greater androgen concentrations in obese boys are responsible for their lower leptin serum concentrations compared with those in obese girls (21). This sexual dimorphism of pubertal changes in leptin concentrations is observed in obese and in normal adolescents (22).

Per kilogram of body fat, boys produce less leptin after than before puberty $(21,22)$. A longitudinal study in eight lean boys suggested that serum leptin increases just before the onset of puberty, possibly because of changes in fat mass, then returns to baseline after the initiation of puberty (31).

We are not aware of longitudinal studies that have been undertaken in girls in normal puberty. Our previous data indicate that, when normalized for body adiposity, circulating leptin is increased independently by obesity status, female sex and sexual maturation. Greater concentrations of leptin in sexually maturing girls, whether lean or obese, are associated with the pubertal increase in fat content (22). Per kilogram body fat, pubertal girls produce approximatively twice more leptin than pubertal boys $(22,29,30)$.
De Ridder et al. (32) studied the rate at which 68 schoolgirls progressed through the stages of puberty in relation to body fat mass. They found no evidence that body fat mass triggers the onset of puberty. Body fat mass, however, was negatively related with the rate of pubertal development toward menarche. According to these observations, onset of puberty and menarche are not parallel events. These findings do not conflict with population data, which suggest that increased fat content accelerates menarche, not puberty onset $(32,33)$.

Given these results, we focused our observations on the perimenarchial or early post-menarchial period. We found that BMI and circulating leptin were statistical negative determinants of gonadotrophin secretion. At or near the end of female puberty, increased adiposity and excess circulating leptin are associated with decreased gonadotrophin secretion. The more obese the pubertal girl, the more leptin secreted and the lower the FSH, LH and FSH response to GnRH. LH and FSH concentrations both decrease in proportion with increasing leptin concentrations, so that $\mathrm{LH} / \mathrm{FSH}$ ratio is conserved. These clinical data are consistent with, but do not establish, leptin as a direct causative signal linking adipose tissue excess to the reproductive function of hypothalamus or pituitary gonadotrophs.

Our results are in apparent contradiction with the effects of leptin observed in animal models of obesity, in which leptin appears to be a physiological signal linking adiposity and central neural networks $(34,35)$. Ob/ob females have a functional defect of the hypothalamicpituitary axis (36-39), and reconstitution of reproductive function requires either delivery of hypothalamic 
extracts to the third ventricle or administration of pituitary extracts or gonadotropic hormones (40). Repeated administration of recombinant human leptin to ob/ob female mice restores hypothalamic-pituitary function and sexual maturity (4), leptin reverses the hypogonadotrophic hypogonadism induced by starvation (40), and leptin treatment of normal female mice accelerates puberty $(7,8)$. Two hypotheses could reconcile these experimental observations with the present results. One is that the central nervous system is resistant to circulating leptin in obese patients (17). If pituitary gonadotroph cells are resistant to leptin in obesity, a signal necessary to sexual maturation and function, this could alter gonadotrophin secretion. The resistance could also act at the blood-brain leptin transport level (41). An alternative hypothesis is that physiological leptin concentrations are necessary for proper female gonadotrophin function during puberty and in the post-pubertal period, but that massively increased leptin concentrations or modifications of secretory rhythms (42) as a result of obesity deregulate the gonadotrophin system. The possibility remains also that serum leptin concentrations are only a reflection of the massive increase of body fat, whereas other circulating or central signals are directly involved in the regulation of gonadotrophin secretion.

Adult women with long-term obesity overexpress the ob gene in their adipose tissue (43), and have increased serum leptin (17). They are at increased risk of developing PCOS, a group of clinical and biological manifestations involving hyperandrogenism, menstrual disturbances, and chronic anovulation. Although the aetiology of PCOS has not been elucidated $(44,45)$, the condition is reminiscent of that in rodents with leptin deficiency or leptin resistance (46). Studies of leptin concentrations in obese women with PCOS at about the age of 30 years of age failed to reveal differences from normally cyclic obese controls (32, 47-51). Although these studies did not find any relationship between increased leptin and PCOS at the time of diagnosis, they do not rule out the possibility that, in subsets of predisposed obese women, increased leptin concentrations may favour the development of PCOS (51). Obese adolescents afford the opportunity to study leptingonadotrophin relationships long before the age at which diagnosis of PCOS is usually made - namely at an age 15 years younger than that of the women with PCOS who were studied $(47,48)$. The marked decrease in gonadotrophin secretion observed in the more obese adolescents could impair ovulation. An inverse correlation of circulating leptin concentration with $\mathrm{LH}$ pulse amplitude has been reported in normal women and those with PCOS. Whether chronically decreased gonadotrophin secretion in adolescence and early sexual maturity could contribute to PCOS pathogenesis remains entirely speculative. None of the adolescent or young women studied had ultrasound or hormonal evidence of PCOS.
In boys, no influence of adiposity or leptin on gonadotrophin concentrations was observed. This could be an additional aspect of the sexual dimorphism of leptin concentrations observed in humans.

\section{Acknowledgements}

We acknowledge the excellent work of M Delacroix on the manuscript, and thank A Dermane for her dedication and contribution to the clinical research.

\section{References}

1 Zhang Y, Proenca R, Maffei M, Barone M, Leopold L \& Friedman JM. Positional cloning of the mouse obese gene and its human homologue. Nature 1995374 479-483.

2 Couce ME, Burguera B, Parisi JE, Jensen MD \& Lloyd RV. Localization of leptin receptor in the human brain. Neuroendocrinology 199766 145-150.

3 Matson CA, Wiater MF \& Weigle DS. Leptin and the regulation of body adiposity. Diabetes Review 19964 488-508.

4 Chehab FF, Lim ME \& Lu R. Correction of the sterility defect in homozygous obese female mice by treatment with the human recombinant leptin. Nature Genetics 199612 318-320.

5 Tartaglia LA, Dembski M \& Weng X. Identification and expression cloning of a leptin receptor, ob-R. Cell 199583 1263-1271.

6 Cioffi JA, Shafer AW \& Zupancic TJ. Novel B219/OB receptor isoforms: possible role of leptin in hematopoiesis and reproduction. Nature Medicine 19962 585-589.

7 Chehab F, Mounzih K, Lu R \& Lim ME. Early onset of reproductive function in normal female mice treated with leptin. Science 1997 $27588-90$.

8 Ahima RS, Dushay J, Flier SN, Prabakaran D \& Flier JS. Leptin accelerates the onset of puberty in normal female mice. Journal of Clinical Investigation 199799 391-395.

9 Chueng CC, Thornton JE, Kuijper JL, Weigle DS, Clifton DK \& Steiner RA. Leptin is a metabolic gate for the onset of puberty in the female rat. Endocrinology 1997138 855-858.

10 Frisch RE. Pubertal adipose tissue: is it necessary for normal sexual maturation? Evidence from the rat and human female. Federation Proceedings 198039 2395-2400.

11 Frisch RE, Hegsted DM \& Yoshinaga K. Body weight and food intake at early estrus of rats on a high fat diet. Proceedings of the National Academy of Sciences of the USA $1975724172-4176$.

12 Frisch RE \& McArthur JW. Menstrual cycles: fatness as a determinant of minimum weight for height necessary for their maintenance or onset. Science $1974185949-951$.

13 Schwartz MW \& Seeley RJ. Neuroendocrine responses to starvation and weight loss. New England Journal of Medicine $19973361802-1811$.

14 Rogers J \& Mitchell GW. The relation of obesity to menstrual disturbances. New England Journal of Medicine 1952247 5354.

15 McLachlan RI, Healy DK \& Burger GH. The ovary: B. Clinical. In Endocrinology and Metabolism, edn 2, pp 957-983. Eds P Felig, JD Baxter, AE Broadus \& LA Frohman. New York: McGraw-Hill, 1987.

16 Hartz AJ, Barboriak PN, Wong A, Katayama KP \& Rimm AA. The association of obesity with infertility and related menstrual abnormalities in women. International Journal of Obesity 19793 57-58.

17 Considine RV, Sinha MK, Heiman ML, Kriauciunas A, Stephens TW, Nyce MR, Ohannesian JP, Marco CC, McKee LJ \& Bauer TL. Serum immunoreactive-leptin concentrations in normal-weight and obese humans. New England Journal of Medicine 1996334 292-295. 
18 Saad MF, Damani S, Gingerich RL, Riad-Gabriel MG, Khan A Boyadjian R, Jinagouda SD, el-Tawil K, Rude RK \& Kamdar V. Sexual dimorphism in plasma leptin concentration. Journal of Clinical Endocrinology and Metabolism 199782 579-584.

19 Kennedy A, Gettys TW, Watson P, Wallace P, Ganaway E, Pan Q \& Garvey WT. The metabolic significance of leptin in humans: gender-based differences in relationship to adiposity, insulin sensitivity, and energy expenditure. Journal of Clinical Endocrinology and Metabolism 199782 1293-1300.

20 Rosenbaum M, Nicolson M, Hirsch J, Heymsfield SB, Gallagher D, Chu F \& Leibel RL. Effects on gender, body composition and menopause on plasma concentration of leptin. Journal of Clinical Endocrinology and Metabolism 199681 3424-3427.

21 Wabitsch M, Blum WF, Muche R, Braun M, Hube F, Rascher W, Heinze E, Teller $W$ \& Hauner $H$. Contribution of androgens to the gender difference in leptin production in obese children and adolescents. Journal of Clinical Investigation $1997100808-$ 813.

22 Lahlou D, Landais P, de Boissieu D \& Bougnères P. Cirulating leptin in normal children and during the dynamic phase of juvenile obesity. Diabetes 199746 989-993.

23 Flier JS \& Underhill LH. Gonadotropin-releasing hormone: role of pulsatile secretion in the regulation of reproduction. New England Journal of Medicine 1986315 1459-1468.

24 Grumbach MM \& Styne DM. Puberty: ontogeny, neuroendocrinology, physiology, and disorders. In Williams Textbook of Endocrinology, edn 8, pp 1139-1221. Eds JD Wilson \& DW Foster. Philadelphia: WB Saunders Company, 1992.

25 Rico H, Revilla M, Villa LF, Hernandez ER, Alvarez de Buergo M \& Villa M. Body composition in children and Tanner's stages: a study with dual-energy X-ray absorptiometry. Metabolism 1993 42 967-970.

26 Poskitt EME. Defining childhood obesity: the relative body mass index (BMI). Acta Paediatrica 199584 961-963.

27 Oerter KE, Uriarte MM, Rose SR, Barnes KM \& Cutler GB. Gonadotropin secretory dynamics during puberty in normal girls and boys. Journal of Clinical Endocrinology and Metabolism 199071 1251-1258.

28 Clayton PE, Gill MS, Hall CM, Tillmann V, Whatmore AJ \& Price DA. Serum leptin through childhood and adolescence. Clinical Endocrinology 199746 727-733.

29 Blum WF, Englaro P, Hanitsch S, Juul A, Hertel NT, Muller J, Skakkebaek NE, Heiman ML, Birkett M. Attanasio AM, Kiess W \& Rascher W. Plasma leptin levels in healthy children and adolescents: dependence on body mass index, fat mass, gender, pubertal stage, and testosterone. Journal of Clinical Endocrinology and Metabolism 199782 2904-2910.

30 Garcia-Mayor RV, Andrade MA, Rios M, Lage M, Dieguez C \& Casanueva FF. Serum leptin in normal children: relationship to age, gender, body mass index, pituitary-gonadal hormones, and pubertal stages. Journal of Clinical Endocrinology and Metabolism 199782 2849-2855.

31 Mantzoros CS, Flier JS \& Rogol AD. A longitudinal assessment of hormonal and physical alterations during normal puberty in boys. V. Rising leptin levels may signal the onset of puberty. Journal of Clinical Endocrinology and Metabolism 197782 1066-1070.

32 De Ridder CM, Thijssen JHH, Bruning PF, Van den Brande JL, Zonderland ML \& Erich WBM. Body fat mass, body fat distribution, and pubertal development: a longitudinal study of physical and hormonal sexual maturation of girls. Journal of Clinical Endocrinology and Metabolism 199275 442-446.

33 Frisch RE. Weight at menarche: similarity for well nourished and undernourished girls at differing ages and evidence for historical constancy. Pediatrics $197250445-450$.
34 Campfield LA, Smith FJ, Guisez Y, Devos R \& Burn P. Recombinant mouse ob protein: evidence for a peripheral signal linking adiposity and central neural networks. Science $1995269546-$ 549.

35 Barash IA, Cheung CC, Weigle DS, Ren H, Kabigting EB, Kuijper JL, Clifton DK \& Steiner RA. Leptin is a metabolic signal to the reproductive system. Endocrinology 1996137 3144-3147.

36 Lane PW. The pituitary gonad response of genetically obese mice in parabiosis with thin and obese siblings. Endocrinology 195965 863-868.

37 Runner MN \& Roscoe B. Inherited hypofunction of the female pituitary in the sterile-obese syndrome in the mouse. Genetics 195439 990-991.

38 Drasner ML, Dickie MM \& Lane PW. Physiological differences in uteri of obese stock mice. Journal of Heredity 195546 209-212.

39 Swerdloff RS, Batt RA \& Bray GA. Reproductive hormonal function in the genetically obese (ob/ob) mouse. Endocrinology 199598 1359-1364.

40 Batt RAL. The response of the reproductive system in the female mutant mouse obese (ob/ob) to gonadotropin releasing hormones. Journal of Reproduction and Fertility 197231 496-497.

41 Ahima RS, Prabakaran D, Mantzoros C, Qu D, Lowell B, MaratosFlier E \& Flier JS. Role of leptin in the neuroendocrine response to fasting. Nature 1996382 250-252.

42 Schwartz MW, Peskind E, Raskind M, Boyko EJ \& Porte D Cerebrospinal fluid leptin levels: relationship to plasma levels and to adiposity in humans. Nature Medicine 19962 589-593.

43 Maffei MJ, Halaas J, Ravussin E, Pratley RE, Lee GH, Zhang Y, Fei H, Kim S, Lallone R \& Ranganathan S. Leptin levels in human and rodent: measurement of plasma leptin and ob mRNA in obese and weight-reduced subjects. Nature Medicine 19951 1155-1161.

44 McKenna TJ. Pathogenesis and treatment of polycystic ovary syndrome. New England Journal of Medicine 1988318 558-562.

45 Franks S. Polycystic ovary syndrome. New England Journal of Medicine $1995333853-861$.

46 Caro JF, Sinha MK, Kolaczynski JW, Zhary PL \& Considine RV. Leptin: the tale of an obesity gene. Diabetes 199645 1455-1462.

47 Brzechffa PR, Jakimiuk J. Agarwal SK, Weitsman SR, Buyalos RP \& Magoffin DA. Serum immunoreactive leptin concentrations in women with polycystic ovary syndrome. Journal of Clinical Endocrinology and Metabolism 199681 4166-4169.

48 Laughlin GA, Morales AJ \& Yen SSC. Serum leptin levels in women with polycystic ovary syndrome: the role of insulin resistance/hyperinsulinemia. Journal of Clinical Endocrinology and Metabolism 199782 1692-1696.

49 Rouru J, Anttila L, Koskinen P, Penttila TA, Irjala K, Huupponen R \& Koulu M. Serum leptin concentrations in women with polycystic ovary syndrome. Journal of Clinical Endocrinology and Metabolism 199782 1697-1700.

50 Mantzoros CS, Dunaif A \& Flier JS. Leptin concentrations in the polycystic ovary syndrome. Journal of Clinical Endocrinology and Metabolism 199782 1687-1691.

51 Caro JF. Leptin is normal in PCOS; an editorial about three 'negative' papers. Journal of Clinical Endocrinology and Metabolism 1997821685 (Editorial).

52 Taylor AE, Martin KA \& Hall JE. Evidence for a reproductive role of leptin: correlation with LH pulse amplitude but not frequency in normal women and polycystic ovary syndrome. 79th Annual Meeting of the Endocrine Society, Minneapolis, Minnesota, USA, 1997, p 121.

Received 12 November 1997

Accepted 16 February 1998 